\title{
The Critically Endangered kipunji Rungwecebus kipunji of southern Tanzania: first census and conservation status assessment
}

\author{
Tim R.B. Davenport, Daniela W. De Luca, Trevor Jones, Noah E. Mpunga \\ Sophy J. Machaga, Amani Kitegile and Guy Picton Phillip s
}

\begin{abstract}
We present the first assessments of the population, distribution and conservation status of the recently described kipunji Rungwecebus kipunji in forests in the Southern Highlands and Udzungwa Mountains of southern Tanzania. Surveys totalling 2,864 hours and covering 3,456 $\mathrm{km}$ of transects were undertaken to determine distribution and group numbers, following which 772 hours of simultaneous multi-group observations in Rungwe-Kitulo and Ndundulu forests, in the Southern Highlands and Udzungwa Mountains respectively, enabled 209 total counts to be carried out. We estimate there are $c .1,042$ individuals in Rungwe-Kitulo, with 25-39 individuals per group (mean $30.65 \pm$ SE $0.62, \mathrm{n}=34$ ), and 75 individuals, with $15-25$ per group (mean $18.75 \pm \mathrm{SE} 2.39, \mathrm{n}=4$ ) in Ndundulu. We estimate a total kipunji population of 1,117 in 38 groups, with 15-39 per group (mean 29.39 \pm SE $0.85, \mathrm{n}=38$ ). The Ndundulu population may no longer be viable and the Rungwe-Kitulo population is highly fragmented, with isolated sub-populations in degraded habitat. We recorded areas of occupancy of 1,079 and 199 ha in Rungwe-Kitulo and Ndundulu, respectively, giving a total of $1,278 \mathrm{ha}$. We estimate the species' extent of occurrence to be 1,769 ha, with 1,241 and 528 ha in Rungwe-Kitulo and Ndundulu, respectively. We believe the kipunji faces an extremely high risk of extinction in the wild and recommend the species and genus be categorized as Critically Endangered on the IUCN Red List.
\end{abstract}

Keywords Census, Critically Endangered, distribution, primate, Rungwecebus kipunji, Tanzania.

\section{Introduction}

The recent discovery of the kipunji Rungwecebus kipunji, 1 a new genus and species of monkey endemic to southern Tanzania (Jones et al., 2005; Davenport et al., 2006), dem-

Tim R.B. Davenport (Corresponding author), Daniela W. De Luca, Noah E. Mpunga, Sophy J. Machaga and Guy Picton Phillipps Wildlife Conservation Society, PO Box 1475, Mbeya, Tanzania.

Trevor Jones Environmental Sciences Research Centre, Department of Life Sciences, Anglia Ruskin University, East Road, Cambridge, CB1 1PT, UK.

Amani Kitegile Udzungwa Ecological Monitoring Centre, Box 99, Mang'ula, Tanzania.

Received 10 March 2007. Revision requested 24 May 2007.

Accepted 25 June 2007. onstrated how much there is still to learn about Africa's montane forests. Kipunji were first located and identified as a new taxon by teams working in the Southern Highlands and Udzungwa Mountains in 2003 and 2004, respectively (Davenport, 2005, 2006; Davenport \& Jones, 2005; Davenport et al., 2005, 2006; Jones et al., 2005). The new taxon was initially placed in the genus Lophocebus (Jones et al., 2005) but subsequent molecular and morphological analyses led to the monkey's placement in a new monospecific genus Rungwecebus, making it the first new genus of African monkey to be described since 1923 (Davenport et al., 2006).

Kipunji are large, group-living, forest-dependent and primarily arboreal monkeys, although on Mount Rungwe they do occasionally leave the forest and move on the ground to raid crops (Davenport, 2005; Davenport et al., 2005, 2006). They are found in submontane and montane forest over 1,300-2,450 m (Davenport et al., 2006) where they form multi-male groups, often associating with other monkey species (Davenport et al., 2005; Davenport \& Jones, 2005). Their diverse diet includes fruit, seeds, leaves, bark, lichen, moss and invertebrates (Davenport et al., 2005, 2006; Davenport, in press; Davenport \& Butynski, in press). Although we speculated that the kipunji may be severely threatened (Davenport, 2005), to implement conservation measures we needed to determine the full extent of the kipunji's distribution and abundance. We therefore carried out systematic investigations to provide the first quantitative assessment of the species' status, both for conservation purposes in Tanzania and to categorize kipunji on the IUCN Red List (IUCN, 2007).

Forest primates are notoriously difficult to survey and many techniques have been suggested (Brockelman \& Ali, 1987; Whitesides et al., 1988; Plumptre \& Cox, 2006; Rovero et al., 2006). The cryptic nature of the kipunji, its scarcity, fear of humans and predilection for montane forest canopy exacerbate the difficulties. Nevertheless, based on our experience with the species and its habitat, we selected methods that would allow us to (1) determine distribution, (2) census the known populations, and (3) provide, based on comprehensive and quantitative data, the first Red List assessment.

\section{Study area}

This study was carried out in two forested areas $350 \mathrm{~km}$ apart. In the Southern Highlands the sites were the Kitulo 
National Park (comprising the Kitulo Plateau and adjacent Livingstone and Numbe forests) as well as the forest reserves of Mount Rungwe, Sawago, Irenga, Irungu, Mporoto Ridge, Madehani and Ndukunduku. In the Udzungwa Mountains the sites were Ndundulu and Nyumbanitu forests within the Kilombero Nature Reserve and Luhomero forest within the Udzungwa Mountains National Park. The habitats comprise submontane, montane, upper montane and bamboo forests over 1,300-2,500 $\mathrm{m}$.

\section{Methods}

Distribution data were collected from May 2003 to September 2006 using presence/absence surveys. Census data were recorded from November 2005 to September 2006 using total counts made during group follows in RungweKitulo and Ndundulu, and a sweep census in Ndundulu in March 2006.

\section{Presence/absence surveys}

Forests were selected for presence/absence surveys based on prior knowledge of the areas, information from previous surveys, interviews with villagers, and the habitat type, quality and altitudinal range from which kipunji were already known. Survey effort at each site was proportional to the area being surveyed. Teams of 2-5 pairs of observers concurrently searched for kipunji along separate pre-planned routes using 1:50,000 topographic maps (Tanzania Surveys and Mapping Division, Series Y742), global positioning systems (GPS) and binoculars. Vocalizations were verified by sightings. New areas were surveyed each day, adjacent to the area covered the previous day. Some areas were revisited if they contained a high density of fruiting trees and other primates or if inclement weather had hindered earlier work. Survey routes followed wildlife trails and human tracks to survey a large area thoroughly. Each team walked slowly and quietly, scanning the understorey and canopy, at $1-2 \mathrm{~km} \mathrm{~h}^{-1}$ between 06.50 and 18.30. When an individual or group was detected the observer remained until confident that the species had been identified. The species, group size estimate, and location were recorded for all primates encountered.

\section{Census}

To ascertain an absolute figure for the kipunji population, rather than an estimate based on density, we adopted the complete count method, widely accepted as being the most accurate primate census technique (Plumptre \& Cox, 2006). To increase accuracy further, we based collection methods on direct observations of individual animals only, adapting the gorilla census methods developed by Harcourt \& Fossey (1981) and McNeilage et al. (2001), who carried out complete counts of indirect sign.
To count all individuals we aimed to locate and follow every kipunji group for a minimum of 5 consecutive days. Once located, a group was followed at a distance that enabled the team to maintain contact but that minimized stress upon the group (usually 20-50 m). Grid reference positions of the group were recorded by GPS every 15 minutes. During follows the numbers of individuals in each group were counted daily, whenever possible. The person counting was always the same in each team. In any forest block kipunji groups were considered unique if: (1) They were seen at the same time by different observation teams, spending more than $75 \%$ of the observation time at a distance of at least $300 \mathrm{~m}$ apart (this was verified a posteriori). (2) One team saw a group other than the one they were following, at least $400 \mathrm{~m}$ away, and later verified that no other team had been near the group. (3) The groups were recorded $>300 \mathrm{~m}$ apart, at the same time, and subsequently moved in different directions. In cases where there was any doubt, at least two teams returned at a later date to verify group identity. We also carried out a 7-day sweep census in southern Ndundulu to verify population size (Jones, 2006). This census, involving three teams walking parallel transects $100-300 \mathrm{~m}$ apart, encompassed $11 \mathrm{~km}^{2}$, which is more than the kipunji's known total extent of occurrence. Teams collected data in the same way as in the presence/absence surveys.

\section{Occupancy and occurrence}

We used the geographical information system (GIS) ArcView v. 3.2 (ESRI, Redlands, USA) to analyse observation data from all groups recorded in the survey and census work. These data permitted a calculation of the area of occupancy, defined as the area within the species' extent of occurrence that is occupied by a taxon, excluding cases of vagrancy (IUCN, 2007). The measure reflects the fact that a taxon will not usually occur throughout the area of its extent of occurrence, which may contain unsuitable or unoccupied habitats. We used the grid method of area of occupancy representation and calculation (Horner \& Powell, 1990; Powell, 2000), whereby a grid of individual cells is overlaid on observation points. As the size of the area of occupancy should be at a scale appropriate to relevant biological aspects of the taxon (IUCN, 2007), cell size should take into account objective information about the radius of an animal's perception, and knowledge of all location data (Powell, 2000). We therefore empirically calculated a cell size of $190 \times 190 \mathrm{~m}$ based on our data of the kipunji's daily movements (one half of the mean of the longest interior distance of daily range polygons being 190 m; D.W. De Luca \& T.R.B. Davenport, unpubl. data). Any grid cell that contained an observation point was thus included in calculation of area of occupancy, and the totals for each group summed. 
A taxon's extent of occurrence is the area contained within the shortest continuous boundary that can be drawn to encompass all the known, inferred or projected sites of present occurrence (IUCN, 2007). We measured the extent of occurrence by calculating the area of minimum convex polygons (the smallest polygons in which no internal angle exceeds 180 degrees and that contains all the sites of occurrence), as defined by IUCN (2007) and using a GIS. As this measure may exclude discontinuities within the overall distribution, such as areas of unsuitable habitat (IUCN, 2007), in Rungwe-Kitulo the polygons were developed around neighbouring and overlapping kipunji groups only, and did not include heavily degraded forest between group clusters with no records of kipunji.

\section{Results}

\section{Presence and absence}

Table 1 illustrates the search effort at each site between 2003, when the kipunji was first sighted during biodiversity inventories (Davenport, 2005; Jones et al., 2005), and September 2006. A total of $3,456 \mathrm{~km}$ were walked in a total of 2,864 team hours, with 3,009 km and $447 \mathrm{~km}$, and 2,497 and 367 hours, in the Southern Highlands and Udzungwa Mountains, respectively. The surveys indicate that the kipunji is restricted to a number of discrete portions of the forests of Mount Rungwe and the adjacent Livingstone forest in Kitulo National Park in the Southern Highlands, and the Vikongwa area of the Ndundulu forest in the Udzungwa Mountains (Figs 1-2). Despite extensive surveys kipunji were not recorded (and are therefore presumed to be absent) in the Sawago, Irenga, Irungu, Mporoto Ridge, Madehani and Ndukunduku Forest Reserves or the Numbe forest in Kitulo National Park, in the Southern Highlands, nor in the Nyumbanitu forest in Kilombero Nature Reserve or Luhomero forest in the Udzungwa Mountains National Park, in the Udzungwa Mountains. The closest record of kipunji to Udzungwa Mountains National Park is $1.9 \mathrm{~km}$ outside the Park boundary. The absence data are further supported by our socio-economic surveys and conservation work in the villages immediately adjacent to the above mentioned forests. None of the villagers, environment committees, hunters or scientists with knowledge of the forests where kipunji were not observed claimed any observations to the contrary (Machaga et al., 2005; Jones, 2006).

\section{Census}

During the census of January-September 2006 a total of $1,025 \mathrm{~km}$ were walked and 1,238 hours spent following

TABLE 1 Total number of team hours spent, km walked and altitudinal range covered in presence/absence surveys for the kipunji and group follows during 2003-2006. The four locations in which kipunji were found are in italics.

\begin{tabular}{|c|c|c|c|c|}
\hline Year(s) & Area & Distance $(\mathrm{km})$ & Team hours & Altitude (m) \\
\hline \multicolumn{5}{|c|}{ Southern Highlands } \\
\hline 2003-2006 & Livingstone West & 277 & 235 & $1,610-2,790$ \\
\hline 2003-2004, 2006 & Rungwe North & 861 & 545 & $1,520-2,660$ \\
\hline 2003-2006 & Rungwe South & 879 & 884 & $1,250-2,980$ \\
\hline 2003, 2005 & Mporoto & 18 & 18 & $1,500-2,620$ \\
\hline 2004 & Numbe & 73 & 69 & $2,500-2,730$ \\
\hline 2004 & Kitulo Plateau & 38 & 17 & $1,570-2,920$ \\
\hline 2004-2005 & Livingstone East & 79 & 68 & $2,110-2,900$ \\
\hline 2004-2005 & Livingstone North & 185 & 149 & $1,980-2,890$ \\
\hline 2004,2006 & Livingstone South & 417 & 319 & $1,820-2,780$ \\
\hline 2005-2006 & Madehani & 123 & 65 & $1,670-2,790$ \\
\hline 2005 & Irungu/Irenga & 35 & 80 & $2,580-2,700$ \\
\hline \multirow[t]{2}{*}{2006} & Ndukunduku & 24 & 48 & $2,200-2,740$ \\
\hline & Total & 3,009 & 2,497 & $1,250-2,980$ \\
\hline \multicolumn{5}{|c|}{ Udzungwa Mountains } \\
\hline 2006 & Luhomero South & 69 & 57 & $1,390-2,000$ \\
\hline 2006 & Ndundulu South & 69 & 57 & $1,400-1,790$ \\
\hline 2006 & Luhomero Central & 18 & 15 & $2,000-2,500$ \\
\hline 2005-2006 & Ndundulu Central & 7 & 5 & $1,800-2,050$ \\
\hline 2006 & Nyumbanitu & 28 & 22 & $1,400-1,800$ \\
\hline 2005-2006 & Ndundulu East & 87 & 71 & $1,300-2,000$ \\
\hline 2005-2006 & Luhomero West & 32 & 27 & $1,700-2,000$ \\
\hline \multirow[t]{2}{*}{$2005-2006$} & Ndundulu Vikongwa & 137 & 113 & $1,300-1,800$ \\
\hline & Total & 447 & 367 & $1,300-2500$ \\
\hline Grand total & & 3,456 & 2,864 & \\
\hline
\end{tabular}




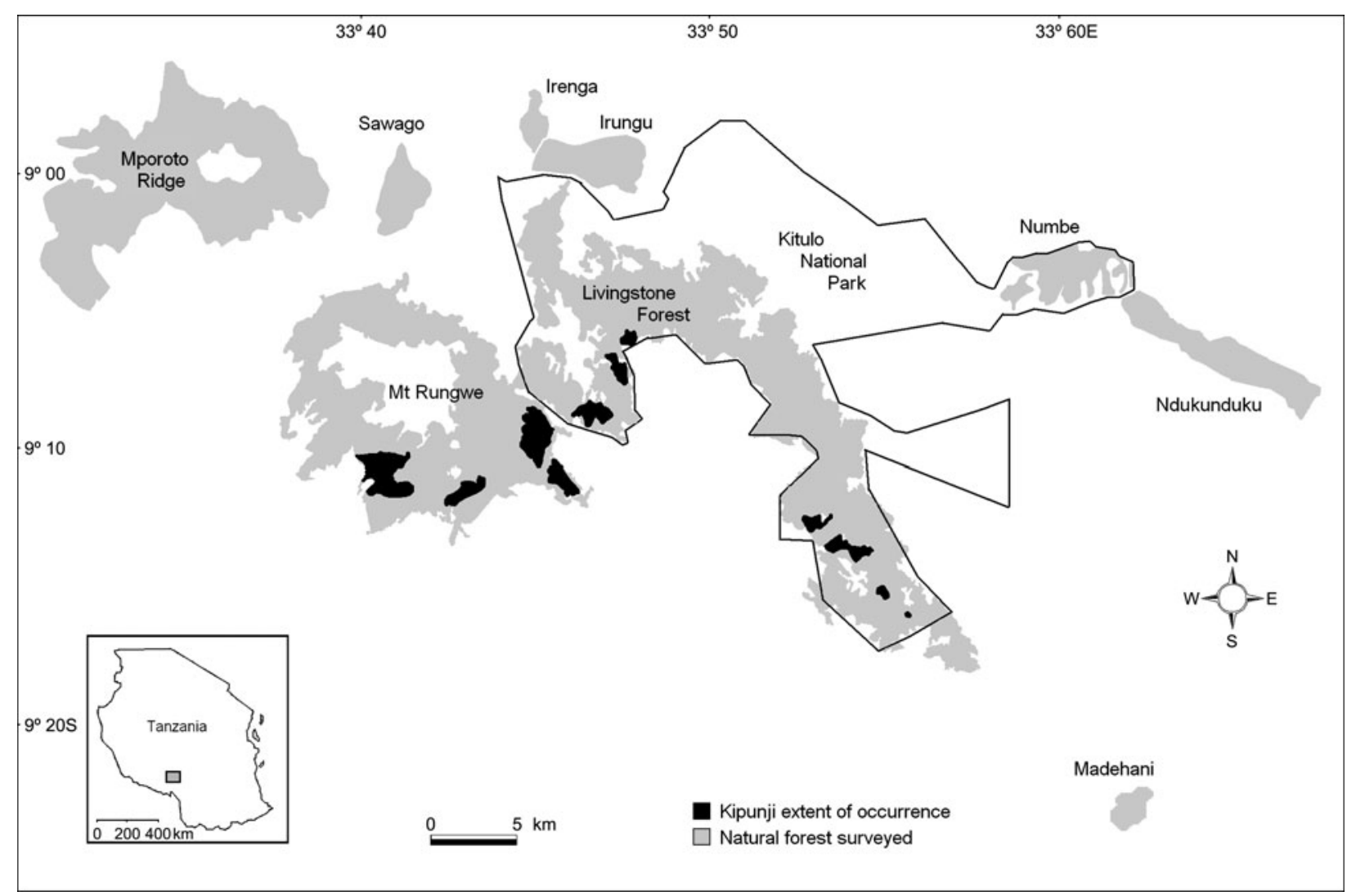

FIG. 1 Forests in the Southern Highlands surveyed for kipunji, and the species' range (extent of occurrence) in the Rungwe-Kitulo forests. Inset indicates the location of the main map in Tanzania.

kipunji in Rungwe-Kitulo. We collected 2,118 spatiallyreferenced observations representing a total of 149 group follows, and identified a total of 34 kipunji groups, of which 205 counts were made (Table 2). We estimate a total of 1,042 individuals in the Southern Highlands, with a mean of $30.65 \pm$ SE 0.62 (range $25-39, \mathrm{n}=34$ ) individuals per group. Of these, 501 individuals in 16 groups were counted in Rungwe and 541 in 18 groups in Livingstone forest of Kitulo National Park. In Ndundulu, in the Kilombero Nature Reserve, $61.3 \mathrm{~km}$ were walked over 132.5 hours, and an additional 49 hours were spent following the four groups that were identified. We estimate a total of 75 animals with a mean of $18.75 \pm$ SE $2.39($ range $15-25, n=4)$ individuals per group. We estimate, therefore, a total kipunji population of 1,117 animals, based on 209 counts of 38 groups during 772 hours of group follows, with a mean of $29.39 \pm$ SE 0.85 (range $15-39, \mathrm{n}=38$ ) individuals per group. Mean group size in the Rungwe-Kitulo and Ndundulu populations were significantly different $(t=4.81$, $\mathrm{df}=3, \mathrm{P}=0.017$ ).

\section{Occupancy and occurrence}

The surveys and group follows permitted a determination of the kipunji's area of occupancy based on all observations made in the grid squares. We calculated area of occupancies of 671.5, 407.9 and 198.6 ha in Mount Rungwe, Livingstone Forest of Kitulo National Park, and Ndundulu, respectively. The total for Rungwe-Kitulo was therefore 1,079.4 ha, and the total species area of occupancy was 1,277.9 ha based on all data collected over 3 years (Table 3 ). We estimate the extent of occurrence for kipunji to be 815.4, 425.4 and 528.3 ha for Mount Rungwe, Livingstone and Ndundulu, respectively. The total for Rungwe-Kitulo was 1,240.8 ha and the estimated total extent of occurrence 1,769.1 ha.

Determining group home range size depends upon an understanding of the extent of overlap between groups. (D.W. De Luca \& T.R.B. Davenport, unpubl. data). However, a raw estimate of density derived from the census data and the estimated extent of occurrence gives 83.9 individuals per $\mathrm{km}^{2}$ in Rungwe-Kitulo, and $14.2 \mathrm{~km}^{-2}$ in Ndundulu (Table 3). The combined species density (within their extent of occurrence and excluding home range overlaps) is $63.1 \mathrm{~km}^{-2}$.

\section{Discussion}

Whilst extrapolative estimates of population size and speculative discussions on the range of the kipunji have been made (Jones et al., 2005; Davenport et al., 2006), our 


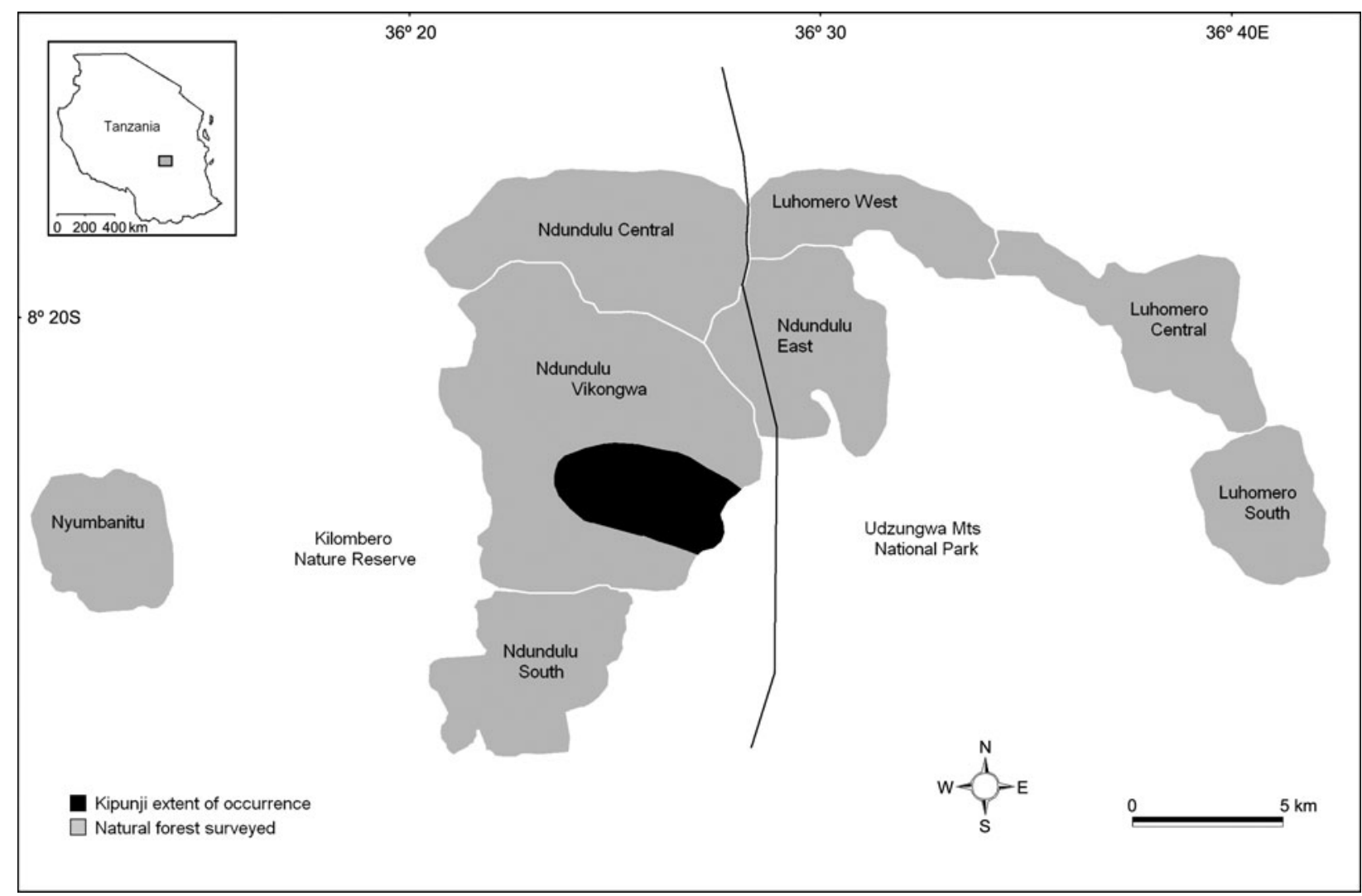

Fig. 2 Forests in the Udzungwa Mountains surveyed for kipunji, and the species' range (extent of occurrence) in Ndundulu forest. Inset indicates the location of the main map in Tanzania.

results provide the first systematically derived data on the abundance and distribution of this new monotypic genus. Many methods have been developed for censusing primate populations (Brockelman \& Ali, 1987; Plumptre \& Cox, 2006) and, although line transect methods have become the most widely used (Struhsaker, 1981, 2002), there is still debate about data analysis and accuracy (Plumptre \& Reynolds, 1996; Struhsaker, 1997; Plumptre \& Cox, 2006; Rovero et al., 2006). Given the urgency for conservation of the kipunji we performed a complete count after a longterm survey, thereby ensuring an accurate population estimate. Kipunji are shy, rare and primarily arboreal (Davenport \& Jones, 2005; Jones et al., 2005; Davenport et al., 2006). However, the considerable survey effort undertaken, our knowledge of the animal gained during continuous study over 2 years, and supporting information provided by socio-economic research (Machaga et al., 2005; Jones, 2006) all provide additional confidence in the accuracy of the data. The survey protocol and remote sensing analyses used to determine habitat type and quality further support our contention that all existing groups in the Southern Highlands have been located. It is possible that there are groups in or near Ndundulu that remain undetected although, in our judgement, it is unlikely.

A total population of 1,117 animals is extremely small. The status of the population in Ndundulu is of particular cause for concern, and given current thinking on primate population sizes (Harcourt, 2002) it may be that it is no longer viable. The causes of this are yet unclear and are currently being investigated. Both the Rungwe and Livingstone forests are heavily degraded (Davenport, 2005, 2006; Davenport \& Jones, 2005), and based on remote sensing analysis of forest cover the extent of connection between the various sub-populations is probably limited. The difference in mean group size between the Rungwe-Kitulo and the Ndundulu populations is significantly different and is the subject of ongoing research. It could be linked to the small total population size in Ndundulu, or to fragmentation, reduced resource patches and food availability in Rungwe-Kitulo, as demonstrated for other species (Chapman et al., 2002, 2003; Struhsaker et al., 2004).

The kipunji is more sparsely distributed than we initially thought (Jones et al., 2005). The total area of occupancy determined by the sum of the occupied grid squares is 12.78 $\mathrm{km}^{2}$ and the total extent of occurrence (the species' range) is just $17.69 \mathrm{~km}^{2}$. The small extent of occurrence in Ndundulu and the patchy distribution in Rungwe-Kitulo give grounds for considerable conservation concern and the total extent of occurrence of $17.69 \mathrm{~km}^{2}$ demonstrated by our data is considerably less than the $100 \mathrm{~km}^{2}$ required to fulfil criterion B of the IUCN Red List (IUCN, 2007) status Critically Endangered (IUCN, 2001). In addition, the range 
TABLE 2 Group identity number, maximum number of individuals counted, number of counts made per group, and number of hours spent per group follow in Rungwe-Kitulo and Ndundulu.

\begin{tabular}{|c|c|c|c|}
\hline Group ID & $\begin{array}{l}\text { Max. no. of } \\
\text { individuals }\end{array}$ & $\begin{array}{l}\text { Counts } \\
\text { per } \\
\text { group }\end{array}$ & $\begin{array}{l}\text { No. of hours } \\
\text { per group } \\
\text { follow }\end{array}$ \\
\hline \multicolumn{4}{|c|}{ Rungwe-Kitulo } \\
\hline 1 & 33 & 2 & 26.13 \\
\hline 2 & 30 & 20 & 47.00 \\
\hline 3 & 27 & 2 & 11.17 \\
\hline 4 & 33 & 4 & 49.08 \\
\hline 5 & 38 & 3 & 42.30 \\
\hline 6 & 29 & 21 & 41.05 \\
\hline 7 & 30 & 2 & 43.78 \\
\hline 8 & 39 & 6 & 9.37 \\
\hline 9 & 25 & 10 & 3.42 \\
\hline 10 & 28 & 8 & 3.20 \\
\hline 11 & 29 & 1 & 3.50 \\
\hline 12 & 30 & 2 & 32.53 \\
\hline 13 & 35 & 5 & 35.60 \\
\hline 14 & 30 & 14 & 6.25 \\
\hline 15 & 33 & 10 & 58.02 \\
\hline 16 & 32 & 1 & 15.35 \\
\hline 17 & 30 & 10 & 47.83 \\
\hline 18 & 32 & 16 & 32.00 \\
\hline 19 & 38 & 3 & 12.50 \\
\hline 20 & 36 & 2 & 12.50 \\
\hline 21 & 33 & 19 & 44.63 \\
\hline 22 & 29 & 10 & 30.03 \\
\hline 23 & 27 & 4 & 6.55 \\
\hline 24 & 28 & 2 & 24.37 \\
\hline 25 & 26 & 8 & 5.00 \\
\hline 26 & 32 & 2 & 11.60 \\
\hline 27 & 27 & 4 & 1.53 \\
\hline 28 & 29 & 2 & 1.50 \\
\hline 29 & 30 & 2 & 4.48 \\
\hline 30 & 32 & 3 & 10.62 \\
\hline 31 & 31 & 2 & 14.00 \\
\hline 32 & 25 & 2 & 3.82 \\
\hline 33 & 26 & 2 & 16.25 \\
\hline 34 & 30 & 1 & 16.25 \\
\hline Total & 1,042 & 205 & 723.22 \\
\hline Mean & $30.65 \pm$ SE 0.62 & & \\
\hline \multicolumn{4}{|l|}{ Ndundulu } \\
\hline 35 & 15 & 1 & 5 \\
\hline 36 & 15 & 1 & 2 \\
\hline 37 & 20 & 1 & 33 \\
\hline 38 & 25 & 1 & 9 \\
\hline Total & 75 & 4 & 49 \\
\hline Mean & $18.75 \pm$ SE 2.39 & & \\
\hline Grand total & 1,117 & 209 & 772 \\
\hline Mean & $29.39 \pm 0.85$ & & \\
\hline
\end{tabular}

is severely fragmented (criterion Bia), and remote sensing analysis of forest loss over the last 20 years in RungweKitulo leads us to infer there has been a decline and that this is continuing. Moreover, the unmanaged state of Mount Rungwe, the continued forest destruction of Mount
TABLE 3 Areas of occupancy (AoO), extent of occurrence (EoO) and density of the kipunji in Mount Rungwe, Livingstone (within Kitulo National Park), combined Rungwe-Livingstone, Ndundulu, and for the species as a whole.

\begin{tabular}{lccc}
\hline & AoO (ha) & EoO (ha) & Density $\left(\mathrm{km}^{-2}\right)$ \\
\hline Rungwe & 671.5 & 815.4 & 61.4 \\
Livingstone & 407.9 & 425.4 & 127.2 \\
Rungwe-Livingstone & $1,079.4$ & $1,240.8$ & 83.9 \\
Ndundulu & 198.6 & 528.3 & 14.2 \\
Total & $1,277.9$ & $1,769.1$ & 63.1 \\
\hline
\end{tabular}

Rungwe and Livingstone Forest in Kitulo National Park, persistent hunting of monkeys across Rungwe-Kitulo, as well as the highly precarious nature of the small population in Ndundulu, leads us to project a continuing decline (criterion $\mathrm{Blb}$ ) in the extent of occurrence, area of occupancy, area, extent and quality of habitat, the number of locations or subpopulations, and the number of mature individuals of kipunji. As a consequence, we propose an IUCN Red List assessment for kipunji of Critically Endangered based on criteria (IUCN, 2001) Biab(i,ii,iii,iv,v), with the genus facing an extremely high risk of extinction in the wild.

An estimated 541 individuals reside within the Livingstone Forest of Kitulo National Park. However, the forest is severely degraded (Davenport, 2006) and illegal activities, including logging and hunting of kipunji, continue. Meanwhile, $>51 \%$ of the total kipunji population lives in Forest Reserves with little or no management. All of these problems are consistent with those facing primates across Africa (Chapman et al., 2006). Immediate focus should be applied to Mount Rungwe, where edge effects, forest clearance and a lack of corridors pose the greatest threats. Across Rungwe-Kitulo the small, isolated sub-populations may already be subject to a loss of genetic variability due to low effective breeding populations and the effects of inbreeding (Frankham, 2002). Some may no longer be viable. Whilst southern Ndundulu is in excellent condition due chiefly to its remote location (Davenport \& Jones, 2005), the longterm viability of this $6.7 \%$ of the population must be considered uncertain at best, although whether any conservation measures could or should be applied in a largely undisturbed habitat is a moot point. The focus of our current kipunji conservation work is the protection and restoration of the montane habitats of Mount Rungwe, research into the reasons for, and viability of, the extremely small Udzungwa population, and local conservation education and long-term monitoring of both populations.

\section{Acknowledgements}

Work in the Southern Highlands was funded by the Wildlife Conservation Society (WCS). We thank in particular an 
anonymous donor, Karen and Dan Pritzker, Ashley Scott and Gary Fink. The Udzungwa work was funded by the Critical Ecosystem Partnership Fund, the Fauna \& Flora International Flagship Species Fund and WCS. Research permission was granted by the Tanzania Wildlife Research Institute, Tanzania Commission for Science and Technology, Tanzania National Parks, Tanzania Forestry and Beekeeping Division, Rungwe District and Udekwa Village Councils. We thank Andrew Ferdinands, Mazao Fungo, Buto Kilasa, Sylvanos Kimiti, Richard Laizzer, Athumani Mndeme, Obadia Mwaipungu, Willy Mwalwengele, Atupele Mwamtobe, Francesco Rovero, Haruna Sauko, Bill Stanley, Link Olson and Eric Sargis for assistance and advice, and three anonymous referees for their valuable comments.

\section{References}

Brockelman, W.Y. \& Ali, R. (1987) Methods of surveying and sampling forest primate populations. In Primate Conservation in the Tropical Rain Forest (eds C.W. March \& R.A. Mittermeier), pp. 23-62. Alan R. Liss, New York, USA.

Chapman, C.A., Chapman, L.J., BJorndal, K.A. \& Onderdonk, D.A. (2002) Application of protein-to-fiber ratios to predict colobine abundance on different spatial scales. International Journal of Primatology, 23, 283-310.

Chapman, C.A., Chapman, L.J., Rode, K.D., Hauk, E.M. \& McDowelL, L.R. (2003) Variation in the nutritional value of primate foods: among trees, time periods, and areas. International Journal of Primatology, 24, 317-333.

Chapman, C.A., Lawes, M.J. \& Eeley, H.A.C. (2006) What hope for African primate diversity? African Journal of Ecology, 44, 116-133.

Davenport, T.R.B. (2005) Finding kipunji. Africa Geographic, 13, 56-61.

Davenport, T.R.B. (2006) Plants, primates and people. Conservation in the Southern Highlands of Tanzania. Miombo, 28, 7-8.

Davenport, T.R.B. (in press) Rungwecebus. In Mammals of Africa (eds T.M. Butynski, D. Happold \& J. Kingdon). Elsevier Press, Oxford, UK.

Davenport, T.R.B. \& Butynski, T.M. (in press) The kipunji Rungwecebus kipunji. In Mammals of Africa (eds T.M. Butynski, D. Happold \& J. Kingdon). Elsevier Press, Oxford, UK.

Davenport, T.R.B. \& Jones, T. (2005) The Highland Mangabey Africa's first new monkey for 20 years further illustrates the exceptional value of Tanzania's forests. Arc Journal, 20, 1-6.

Davenport, T.R.B., Jones, T., Mpunga, N.E., Machaga, S.J., De Luca, D.W., Laizzer, R. et al. (2005) The Highland Mangabey Lophocebus kipunji, Africa's 'Newest' Monkey. Unpublished Proceedings of the Fifth Annual Scientific Conference. Tanzania Wildlife Research Institute, Arusha, Tanzania.

Davenport, T.R.B., Stanley, W.T., Sargis, E.J., De Luca, D.W., Mpunga, N.E., Machaga, S.J. \& Olson, L.E. (2006) A new genus of African monkey, Rungwecebus: morphology, ecology, and molecular phylogenetics. Science, 312, 1378-1381.

Frankham, R., Ballou, J.D. \& Briscoe, D.A. (2002) Introduction to Conservation Genetics. Cambridge University Press, New York, USA.

Harcourt, A.H. (2002) Empirical estimates of minimum viable population sizes for primates: tens to tens of thousands? Animal Conservation 5, 237-244
Harcourt, A.H. \& Fossey, D. (1981) The Virunga gorillas: decline of an island population. African Journal of Ecology, 19, 83-97.

Horner, M.A. \& Powell, R.A. (1990) Internal structure of home ranges of black bears and analyses of home-range overlap. Journal of Mammalogy, 71, 402-410.

IUCN (2001) 2001 Categories and Criteria (version 3.1). IUCN, Gland, Switzerland [http://www.iucnredlist.org/info/categories_criteria2001, accessed 6 March 2007].

IUCN (2007) 2007 IUCN Red List of Threatened Species. IUCN, Gland, Switzerland. Http://www.iucnredlist.org [accessed 6 March 2007].

Jones, T. (2006) Kipunji in Ndundulu Forest, Tanzania: Distribution, Abundance and Conservation Status. Unpublished report for the Critical Ecosystem Partnership Fund, Fauna \& Flora International, and the Wildlife Conservation Society [http://www.cepf. net/xp/cepf/static/pdfs/Jones_kipunji_report_2006_website.pdf, accessed 28 May 2007].

Jones, T., Ehardt, C.L., Butynski, T.M., Davenport, T.R.B., Mpunga, N.E., Machaga, S.J. \& De Luca, D.W. (2005) The highland mangabey Lophocebus kipunji: a new species of African monkey. Science, 308, 1161-1164.

Machaga, S.J., Massawe, A.A. \& Davenport, T.R.B. (2005) Food, Fuel and Fitness. Quantifying Natural Resource Use on Mt Rungwe. Unpublished Proceedings of the Fifth Annual Scientific Conference. Tanzania Wildlife Research Institute, Arusha, Tanzania.

McNeilage, A., Plumptre, A.J., Brock-Doyle, A. \& Vedder, A. (2001) Bwindi Impenetrable National Park, Uganda, gorilla census, 1997. Oryx, 35, 39-47.

Plumptre, A.J. \& Cox, D. (2006) Counting primates for conservation: primate surveys in Uganda. Primates, 47, 65-73.

Plumptre, A.J. \& Reynolds, V. (1996) Censusing chimpanzees in the Budongo forest, Uganda. International Journal of Primatology, $17,85-99$.

Powell, R.A. (2000) Animal home ranges and territories and home range estimators. In Research Techniques in Animal Ecology (eds L. Boitani \& T.K. Fuller), pp. 65-110. Columbia University Press, New York, USA.

Rovero, R., Struhsaker, T.T., Marshall, A.R., Rinne, T.A. Pedersen, U.B., Butynski, T.M. et al. (2006) Abundance of diurnal primates in Mwanahina Forest, Udzungwa Mountains, Tanzania: a multi-observer comparison of line-transect data. International Journal of Primatology, 27, 675-697.

STRUHSAKer, T.T. (1981). Census methods for estimating densities. In Techniques for the Study of Primate Population Ecology (ed. National Research Council), pp. 36-80. National Academy Press, Washington, DC, USA.

Struhsaker, T.T. (1997) Ecology of an African Rain Forest. University Press of Florida, Gainesville, USA.

Struhsaker, T.T. (2002) Guidelines for Biological Monitoring and Research in Africa's Rain Forest Protected Areas. A report to the Center for Applied Biodiversity Science, Conservation International, Washington, DC, USA.

Struhsaker, T.T., Marshall, A.R., Detwiler, K.M., Siex, K., Ehardt, C.L., Lisbjerg, D.D. \& Butynski, T.M. (2004) Demographic variation among the Udzungwa red colobus (Procolobus gordonorum) in relation to gross ecological and sociological parameters. International Journal of Primatology, 25, $615-658$.

Whitesides, G.H., Oates, J.F., Green, S.M. \& Kluberdanz, R.P. (1988) Estimating primate densities from transects in a West African rainforest: a comparison of techniques. Journal of Animal Ecology, 57, 345-367. 


\section{Biographical sketches}

Tim Davenport has worked in the UK, Uganda and Cameroon, and is Country Director for the Wildlife Conservation Society (WCS) in Tanzania. He set up the WCS Southern Highlands Conservation Programme (SHCP) in 2000. Daniela De Luca is the SHCP's Technical Advisor, specializing in carnivore and threatened species ecology, conservation and monitoring. TREVOR JONES runs several research and capacity-building projects in Tanzania and Scotland, and is carrying out research on predictors of mammalian abundance. $\mathrm{NOAH}$ Mrunga and Sophy Machaga are the SHCP's Assistant Director and Senior Conservation Biologist, respectively. Noah's research focuses on carnivore and primate ecology, ethnozoology and conservation management, and Sophy has interests in mammal biology, biodiversity and hunting studies, and GiS. Amani Kitegile is the Co-ordinator of the Udzungwa Ecological Monitoring Centre, with an interest in primate feeding ecology. Guy Picton Phillipps is the East African Remote Sensing and GIS Technical Advisor for WCS. 